\title{
REVIEW
}

\section{Recovery and Recolonization of Coral Reefs}

\author{
R. G. Pearson \\ Queensland Fisheries Service, P.O. Bungalow, Cairns 4870, Australia
}

\begin{abstract}
While considerable attention has focussed on factors responsible for damaging coral communities, few studies have been made of the recovery of coral communities following natural and man-made disturbances. This contribution reviews studies of recovery following various disturbances such as cyclones, volcanic activity, catastrophic low tides, man-made disturbances and Acanthaster planci infestations. In addition some results are presented of the author's long-term studies of recovery following Acanthaster infestations on the Great Barrier Reef. From the evidence available it appears that coral communities require at least several decades to recover from major natural disturbances. The situation is not as clear following man-made disturbances where the environment may have undergone permanent change. Recovery can take place by the regeneration of partially damaged colonies and of fragments produced by mechanical damage during storms. However in most instances recovery occurs through recolonization of denuded areas by settlement of coral larvae. Factors are discussed which can influence coral recolonization and hence recovery. They include the extent of damage and its location, the availability of coral larvae, the requirement for a 'conditioning' period of the substratum before corals can settle, the availability and diversity of micro-habitats for settlement and survival, the role of grazers, and competition with other organisms such as algae and soft corals. Future quantitative studies of recovery should include more long-term investigations covering a wide geographic range and incorporating various reef habitats where adequate base-line data are available. A proper understanding of the recovery process will necessitate examination of not only the factors influencing coral recolonization but also the ways in which they themselves are modified by disturbances. Before this can be achieved it is essential that a basic knowledge of coral life histories be acquired.
\end{abstract}

\section{INTRODUCTION}

Few long-term quantitative studies have been made of the dynamics of coral communities, including both normal or undisturbed assemblages and those disturbed by natural and man-made influences. The intention of this contribution is to review studies of the recovery of coral communities following disturbances, to incorporate some of my own data on recovery of reefs of the Great Barrier Reef damaged by Acanthaster planci infestations and to discuss some of the factors influencing recovery and recolonization. For the purpose of this review I define coral recovery as the restoration following a disturbance of a coral assemblage to a degree comparable to its original state. This can take place by coral recolonization and by coral regeneration. Coral recolonization I define as the settlement of planular larvae on a substratum made available through disturbance of the coral community Coral regeneration, on the other hand, is the regrowth of individual coral colonies following partial damage and includes the re-establishment of fragments broken off parent colonies.

\section{MEASUREMENT OF RECOVERY}

Johannes (1975) referred to some of the problems associated with measuring the extent of recovery. Most studies used species diversity and percentage cover as indices of recovery. Coral reefs, together with tropical rain forests are universally regarded as being the most diverse and stable ecosystems. Yet on a scale of tens and even hundreds of square metres, coral assemblages can exhibit very low diversity, sometimes consisting of just a single species. Diversity in itself may not be a good indication of recovery since it may change with time. Moreover some workers, e. g. Hedgpeth (1973) and Johannes (1975), have queried whether higher diversity necessarily indicates that a community is healthier or in a more natural state. On a related point Johannes (1975) suggested that it would be instructive to compare the original and recovered coral community in terms of similarity of species. Even though their diversity indices may be similar, the communities may be quite different if species similarity is low.

Most workers have used percentage cover as an 
index of recovery simply because space for settlement is so crucial to sessile organisms like corals. However, while it is relatively easy to measure on the reef flat where substratum relief may be only a few centimetres, it is more difficult on reef slopes where the relief can sometimes be measured in metres. Thus there is the problem of comparison of coral coverage on a variety of slopes from horizontal to vertical and on undersurfaces. Pichon (1978) has discussed some of these problems. Further problems in measurement occur because of the tendency of corals in deeper water to overtop one another.

Johannes (1975) suggested that any index of coral recovery would be improved if measurements of mean colony-height were incorporated. Dahl (1973) had already introduced a related measure which he termed surface index (the ratio of the actual surface to that of a plane). He presented a series of geometric approximations of reef surfaces at several different scales ranging from general reef topography such as spurs and grooves, through a variety of standardized colony growth forms, down to the surface of individual coral calices. For a planula which is searching for a suitable substratum on which to settle the latter surface may be of greatest importance. Dahl showed that the height of the surface features and their frequency were very important in determining the surface index. For a typical reef-crest community in the Caribbean he calculated that the actual surface area was at least 15 times the horizontal area.

Unfortunately there appear to be no studies of recovery which have incorporated all these measures, i.e. percentage cover, mean colony-height, surface index, species diversity and similarity indices.

\section{DAMAGE TO CORAL COMMUNITIES}

Many descriptions exist in the literature of the damage sustained to coral communities by natural events such as cyclones, red tides, unusually low tides, volcanic activity; and also by man-made disturbances such as dredging, blasting (including nuclear explosions), oil pollution and deleterious coastal land development. Recent reviews of damage are given by Johannes (1975) and Endean (1976). It is significant that both authors devote much less space to reviewing recovery of coral communities, reflecting the smaller number of studies which have been made.

I propose to examine in some detail what is known of coral recovery following damage caused by natural and human disturbances. Acanthaster will be treated separately since there is still debate as to whether these infestations are natural or caused by man's activities (see Endean, 1977 and Frankel, 1977 for opposing views).

\section{RECOVERY OF CORAL COMMUNITIES FOLLOWING NATURAL DISTURBANCES}

A distinction is drawn between reef slopes and reef flats since the former exist in a usually-stable physical environment whereas the latter are regularly subjected to considerable fluctuations in the physical environment.

\section{Reef-Slope Communities}

\section{Cyclones}

In examining the literature it is surprising to find that there are almost no quantitative studies of recovery following cyclone (= hurricane, typhoon) damage.

In a series of papers, Stoddart $(1963,1969,1974)$ reported on perhaps the longest period of observations made of cyclone damage and recovery following Hurricane Hattie which struck British Honduras reefs in October 1961. During a resurvey made in 1965, he reported 'total destruction of living corals and absence of regeneration: extending at least 15 miles north of the storm track and 12 miles south' (Stoddart, 1969). Many of Stoddart's observations were made from an aircraft flying low over a clear calm sea. Some underwater observations confirmed the aerial observations but no quantitative data were obtained on the numbers, sizes and species of corals. The area was resurveyed again in 1972 (Stoddart, 1974) and, although the methods used were not mentioned, he found little change in the situation. On the basis of his pre-1972 observations Stoddart (1969) predicted that it might take $20-25 y$ for the worst-affected reefs to recover. After the 1972 resurvey he revised this estimate and suggested that it might take $60-100 y$ for complete recovery in areas of maximum damage. He concluded by stating that an average period of about $30 \mathrm{y}$ may be required for recovery since this is about the period of major hurricane frequency along the British Honduras coast (Stoddart, 1974).

In contrast to Stoddart's observations, Shinn (1972) reported that following Hurricanes Donna (in September 1960) and Betsy (in September 1965), storm damage to Florida's reefs could not be recognized by early 1965 (after Hurricane Donna) and by late 1967 (after Hurricane Betsy). According to Shinn the reefs recovered rapidly because coral larvae were able to settle on freshly exposed substrata and many broken coral branches remained alive and quickly re-established new colonies.

It is difficult to reconcile these contrasting rates of recovery. Stoddart (1974) suggested that it might be because Hurricane Hattie caused much greater dam- 
age than Hurricanes Donna and Betsy and that there is a threshold of damage beyond which storm effects are likely to be prolonged.' The lack of any quantitative studies of the pre-storm coral communities, of the degree of damage sustained and of subsequent recovery makes any comparison difficult. It does appear, however, that the pre-storm reefs were different in that the Florida reefs were dominated by colonies of the heavy branched Acropora palmata and staghorn coral A. cervicornis (Shinn, 1963, 1972; Gilmore and Hall, 1976), whereas the British Honduras reefs were composed of a more mixed assemblage including many large massive colonies of Montastrea, Diploria and Siderastrea, Acropora palmata, as well as the more delicate $A$. cervicornis (Stoddart, 1963).

Apart from the intensity of major storms, their frequency appears to be another important factor in determining both the extent of damage and of subsequent recovery. Baines et al. (1974) described the extensive damage caused by Cyclone Bebe to the reef slopes of Funafuti Atoll. This reef which lies outside a major storm belt has experienced only three major storms in the last $100 \mathrm{y}$. On the other hand, Guam, which lies within a major storm belt, has experienced three severe typhoons since 1900 and numerous less severe storms in the past $30 \mathrm{y}$ or so (Randall and Eldredge, 1977; Ogg and Koslow, 1978). These authors reported that following Typhoon Pamela in May 1976, rated the third most intense typhoon to strike Guam this century, reef damage was patchy or superficial with only a few small areas suffering extensive damage. Randall and Eldredge concluded that Guam's reefs were 'well adjusted to unpredictable storm waves generated by typhoons.' Ogg and Koslow considered that the frequent, albeit patchy, cropping of coral assemblages by both major and minor storms could maintain a variety of successional stages in the reef community as well as preserving the low, rugged reef profile characteristic of Guam's reefs. Davies et al. (1971), in their study of the reef slopes of Aldabra Atoll which lies outside a major storm belt, found extensive growths of branching and foliaceous corals. They suggested studying the reefs of the northern Maldives and Laccadives which occur within a major storm belt to see if coral assemblages were similar to those at Aldabra Atoll, or whether slower-growing and less-easily damaged massive corals had received a competitive advantage. To date this has not been attempted nor have more recent reports of recovery of the reefs of Funafuti Atoll and Guam become available. However, Ogg and Koslow (1978) did mention that within 18 months of Typhoon Pamela, newly recruited corals were replacing the algal community which had quickly developed in extensively damaged areas. One can only agree with their statement that 'The incidence of typhoons and their short and long-term effects should be more consistently noted in the future so that we can better understand the dynamics of coral reefs in relation to these natural catastrophes'.

Apart from the frequency and intensity of storms, a factor which is likely to hamper recovery is the presence of extensive beds of loose rubble produced as a result of storms, since any corals which do settle on such unstable substrata have little chance of survival (Stephenson et al., 1958; Goreau, 1959; Stoddart, 1969. 1974).

For the Great Barrier Reef some quantitative data are available on cyclone damage and recovery. In several papers, Connell $(1973,1976,1978)$ presented data on his long-term study of several permanent metre-quadrats established on Heron Island Reef in 1962. Since then two cyclones have passed near the island, one in January 1967 and the other in April 1972. These storms caused extensive damage to some sections of the reef crest and upper reef slopes but not to other areas which were protected by an adjacent reef. All corals were killed by the 1967 cyclone in a one-metre quadrat located in a shallow pool on the unprotected northern reef edge. Before the cyclone there were 43 colonies belonging to 13 species and coral cover was about $57 \%$. Connell (1973) reported that: 'In $2 \frac{1 / 2}{2}$ years after the hurricane, few corals were attached; after $3 \frac{1 / 2}{2}$ years about $10 \%$ of the surface was occupied, and after $41 / 2$ years about $20 \%$ : Later data (Connell, 1978; his Fig. 2A) showed that the number of species in the metre-quadrat, after dropping from 13 to 0 rose to 11 by July 1970, then dropped slightly to 9 in 1971 and rose to 10 in 1972. The second cyclone, in April 1972, caused further damage to the recovering corals in this quadrat. Before this cyclone, coral cover was about $27 \%$ with 10 species. Afterwards coral cover was reduced to about $4 \%$, although there were still 10 species. Again the community recovered so that by 1974, coral cover was about $34 \%$ with 14 species. Connell observed that regrowth in 1974 was not so extensive that diversity was beginning to be reduced through competitive exclusion (Connell, 1978).

Although data from one square metre are insufficient to make generalizations about coral damage and recovery, additional data in support of Connell's studies were given by Woodhead (Appendix E, in Walsh et al., 1971). Woodhead observed that immediately after the January 1967 cyclone, large areas of the reef slope on the northern side of Heron Island Reef, were 'devoid of coral'. A few months after this cyclone Connell (1978; his Fig. 2B) found that coral cover along two $20 \mathrm{~m}$ line transects in the same area was only $2 \%$ and $4 \%$. In June $1970,3 \frac{1}{2} 2$ y after the storm, I assisted Woodhead in making a re-survey of this denuded area. The results of three transects made parallel to the reef 
Table 1 Summary of 3 transect surveys made in June 1970 of the upper reef slope, Heron Island Reef, the northern side of which was extensively damaged by Cyclone Dinah in January 1967 Data from Woodhead's detailed report to Starfish Committee (summarized in Walsh et al., 1971). Quadrats separated by $1-m$ intervals. Means \pm 1 S.D

\begin{tabular}{|c|c|c|c|}
\hline $\begin{array}{l}\text { No. metre } \\
\text { quadrats }\end{array}$ & $\begin{array}{c}\text { Transect } 1 \\
25\end{array}$ & $\begin{array}{c}\text { Transect } 2 \\
20\end{array}$ & $\begin{array}{c}\text { Transect } 3 \\
20\end{array}$ \\
\hline$\%$ coral cover & $27.0 \pm 10.7$ & $24.5 \pm 9.4$ & $19.4 \pm 8.2$ \\
\hline No. colonies $\mathrm{m}^{-2}$ & $16.8 \pm 3.5$ & $16.6 \pm 4.7$ & $13.9 \pm 4.0$ \\
\hline No species $\mathrm{m}^{-2}$ & $9.8 \pm 2.9$ & $9.1 \pm 2.2$ & $8.8 \pm 2.0$ \\
\hline
\end{tabular}

edge in depths of $3-5 \mathrm{~m}$, are represented in Table 1 . By mid 1971, 4 1/2 y after the cyclone mean coral cover had increased to $38 \%$, the mean number of colonies $\mathrm{m}^{-2}$ had increased to 24.5 and the mean number of species $\mathrm{m}^{-2}$ to 15 (P. Woodhead, pers. comm.). These figures indicate more rapid recovery than those by Connell (1978). Dominant species were fast-growing plate forms of Acropora, but other species including massive colonies were represented. On the basis of a good coverage of well-developed colonies before the 1967 cyclone and the fact that the previous major cyclone happened 20 y earlier, Woodhead concluded that complete recovery of corals occurred in $20 \mathrm{y}$ or less.

\section{Volcanic Activities}

Some of the earliest observations of recovery of coral communities were reported by Sluiter (1889) and Umbgrove (1930) following eruption of the volcano at Krakatoa in 1883. Sluiter stated that, by 1888 , corals were growing on basaltic boulders. In 1929 (i. e. 46 y later) when Umbgrove revisited these areas he found no corals (Umbgrove, 1930). He attributed the absence of corals to the great quantities of pumice material falling from the steep cliffs and smothering the corals. It would be useful to examine the coral communities on Krakatoa today.

Grigg and Maragos (1974) provided a welldocumented study of coral recolonization on submerged larva flows in Hawail. Accurate records had been kept of larva flows after 1801 This enabled the authors to select six flow sites ranging in age from 1.6 to $102 \mathrm{y}$ on which to examine recolonization. By comparing the coral communities established on successively older flow sites to each other, and to undisturbed control communities near each flow, they were able to reconstruct patterns of community succession and to distinguish biotopic differences. Two factors simplified their study of recolonization. Firstly, sterile conditions preceded colonization of the larva flows. Secondly, coral diversity is much lower on Hawailan reefs where there are only 12 common shallow water genera $(32$ species), compared with 68 genera (Pichon, 1977), and probably more than 300 species on the Great Barrier Reef. On the Great Barrier Reef, Acropora alone comprises probably over 50 species (Wallace, 1978), whereas from Hawailan reefs only 3 species have been. reported ( $R$. Grigg, pers. comm.). From their studies Grigg and Maragos estimated that recovery of some coral communities would take about $20 y$, whereas others might take $50 \mathrm{y}$ or more. The difference in recovery times was related to the degree of exposure to sea and swell. Succession in exposed areas appeared to be constantly interrupted, resulting in pioneer stages which were able to recover quickly. In sheltered areas, recovery took longer because the coral communities had developed nearer to a climax situation. Several other interesting observations were made by Grigg and Maragos. Firstly, Pocillopora dominated the youngest flow confirming that it is a pioneer species. Secondly, some corals such as Montipora verrucosa did not settle on flows younger than $10 \mathrm{y}$ indicating that the substratum may need to be 'conditioned' before some species can settle. Thirdly, diversity rose to a maximum, then declined before the climax stage was reached. They attributed the decline in diversity to increased interspecific competition for space as more colonies settled and grew. As coral cover increased, diversity decreased. Some species assumed a competitive advantage either through extracoelenteric digestion (Lang, 1970), overtopping (Connell, 1973) or more rapid growth. Grigg and Maragos considered that diversity was unlikely to increase unless some external disturbance interrupted the successional process. They further suggested that Hawaiian coral reefs with a diversity peak at an intermediate stage may represent physically controlled communities and that more diverse coral communities in apparently-stable physical environments such as those found in deep water in the Red Sea (Loya, 1972) may represent biologically controlled communities (Sanders, 1968). Whether the much lower diversity of the Hawaiian coral fauna is of significance in this regard has yet to be determined.

\section{Chilling}

In a study of reefs in the Persian Gulf, Shinn (1972) noted the occurrence of extensive thickets of dead colonies of branching Acropora while less common massive corals were unaffected. He concluded that the cause of this widespread mortality was an unusually severe cold front coupled with strong winds, which drastically lowered water temperatures in January 1964. Although few details are given, Shinn observed that recovery was underway $1.7 \mathrm{y}$ after the chill; by 
1968 the reef had substantially recovered. Shinn considered that recovery had occurred by larval settlement and growth from undamaged reefs over $60 \mathrm{~km}$ away, rather than from the regenerated portions of partially living colonies

\section{Red Tides}

There appears to be only one example in the literature of red tides damaging reefs and of subsequent reef recovery. Smith (1975) reported on damage sustained to reef communities in the Gulf of Mexico following a major red tide in 1971. Most fish and invertebrates including corals died. The worst-affected areas were located 15-32 miles offshore in depths of $18-33 \mathrm{~m}$. While fish and benthic algae recolonized these areas within a year or so, corals and echinoderms had not returned after $2.7 \mathrm{y}$. Smith concluded that although red tides and subsequent mass mortalities were a rare event, they were an important factor in inhibiting the evolution of a climax or equilibrium community.

There appear to be no other factors likely to cause extensive damage to reef-slope coral communities other than Acanthaster (p. 110) and perhaps earthquakes (Stoddart, 1972).

\section{Reef-Flat Communities}

Reef-flat coral communities exist in a harsher environment than do reef-slope communities. They can be damaged by a number of factors such as sedimentation, and extremes of temperature and salinity which coincide with periods of emergence.

\section{Catastrophic Low Tides}

In contrast to severe storms which can cause extensive damage to reef slopes down to about $20 \mathrm{~m}$ (Baines et al., 1974; Pearson, $1975 \mathrm{a}$; Ogg and Koslow, 1978), the occurrence of abnormally low tides are most unlikely to affect corals on the reef slope. But on reef flats the damage can be extensive and has been documented by several authors, notably Yamaguchi (1975) and Loya (1976a). In 1972 a combination of local weather conditions and anomalies in general oceanographic conditions at Guam produced the greatest sealevel fall in $26 y$ of records (Yamaguchi, 1975). This resulted in wide-spread mass mortalities of reef organisms including corals. According to Yamaguchi, recovery was incomplete after $3 y$.

In a far more detailed study, Loya (1976a) compared the recovery patterns of two coral communities on reef flats in the Red Sea which had experienced $80 \%$ to $90 \%$ mortality following an unusually low tide in September 1970 . One reef flat suffered from chronic oil and mineral pollution following the event. The coral communities of the two reef flats were quite similar prior to the catastrophic low tide and mortalities immediately afterwards were not significantly different; however recovery of the two areas differed considerably. After $3 y$, recovery on the non-polluted reef flat was remarkably well-advanced and Loya estimated that it would take 5 or 6 y for complete recovery. On the polluted reef, recovery was significantly less in terms of number of species, percentage coral cover and number of colonies of the more common species. On both reef flats recovery proceeded in two ways: from the regeneration of partially-killed colonies which generally took less than $1 \mathrm{y}$, and from the settlement of coral planulae originating from undamaged subtidal communities. Loya found a significant difference between the two reefs in terms of the number of recolonizers. Whereas the proportion of surviving corals was similar in both areas, recolonization was 23 times greater in the unpolluted than in the polluted area. Loya considered that the low rate of recolonization on the polluted reef was due to pollution harming the reproductive system of corals, decreasing the viability of coral larvae, or changing some physical properties of the reef flat thus interfering with normal settlement of coral larvae. In a later study the first two factors were demonstrated to occur (Rinkevich and Loya, 1977). With respect to recovery of the unpolluted reef flat Loya made several interesting findings. Firstly, the commonest species prior to the catastrophic low tide had the highest rates of recruitment after the event. According to Loya, some corals appeared to have adopted a life history strategy which enabled them to succeed in the more unpredictable reef flat environment. Ways in which opportunistic corals can achieve this include high rates of reproduction, growth and dispersal, and wide physiological tolerances. Secondly, there were more species and colonies $3 \mathrm{y}$ after the event than before it. Thus it appears that diversity increases to a maximum at a successional stage prior to the climax community (Grigg and Maragos, 1974). Then, as the growing colonies begin to compete with one another, the opportunistic species are excluded so that diversity is lowered. However, unpredictable events such as extreme low tides interrupt this process and the reef-flat coral community never attains the climax stage.

While there exist a number of other references (in Loya, 1976a) to damage sustained by reef-flat coral communities during periods of exposure, detailed studies of subsequent recovery are lacking. There are a 
few instances of non-recovery of reef-flat coral communities for long periods following natural catastrophic events such as floods (Wood-Jones, 1907; Hedley, 1925; Rainford, 1925; Stephenson et al., 1958). In a study of the lagoon reefs of Tahiti, Crossland (1928) reported extensive damage to corals following a flood in January 1926. By August 1928 the dominant corals on the reef flat, Acropora formosa and Pocillopora damicornis, were dead and overgrown with calcareous algae. In contrast, on the reef slopes 'where corals had been killed to a depth of a fathom or so, things were quite different, the whole surface being covered with corals of fair size in a flourishing condition' (Crossland, 1939). As these early studies were not well documented it is difficult to determine whether nonrecovery was due to a permanent change in the environment or whether conditions for coral growth were only marginal prior to the disturbance.

\section{RECOVERY OF CORAL COMMUNITIES FOLLOWING MAN-MADE DISTURBANCES}

In contrast to naturally occurring catastrophic events, man-made disturbances are more likely to result in permanent change to the environment, so that recovery of coral communities may be prolonged, altered considerably, or even prevented. Examples of human influences responsible for damage include chronic pollution, dredging and blasting (which can also alter current-flow rates and patterns and sediment levels), increased run-off and sediment loads resulting from land clearance and use. These influences and others have been discussed by Johannes (1975) and Endean (1976).

While numerous cases of human-caused damage to coral reefs exist in the literature, few detailed investigations of long-term aftereffects are available. One reason for this, as stated by Dahl and Lamberts (1977), is that there is a lack of adequate baseline data from which to measure change'. One notable exception is Loya's recent study in the Red Sea mentioned previously. Another one is the re-survey by Dahl and Lamberts (1977) of Mayor's detailed studies of Samoan coral reefs made in 1917 (Mayor, 1924). Mayor conducted a series of transect measurements over the reef flat in Pago Pago harbour; of these only two crossed still living reef in 1973, the other reef parts had disappeared with dredging and filling operations in the harbour. In one transect which Dahl and Lamberts examined in detail there were significant changes in the total number of colonies and in the relative proportions of 4 common genera. There was also some evidence to show that average colony size had declined indicating that recovery was in progress, presumably because of the presence of many small colonies. However, Dahl and Lamberts were unable to attribute these changes to any specific natural or human disturbances.

Perhaps the most serious example of human disturbance concerns Kaneohe Bay, Oahu, Hawaii, where a combination of sedimentation and eutrophication caused the destruction of many coral reefs in the bay. Banner (1974) in a review of the situation concluded that unless all new pollution was stopped immediately the reefs would not recover. He painted a gloomy picture of the reef's chances of recovery as land development was still proceeding around the bay at the time of writing and was likely to continue beyond 1977.

While these examples demonstrate that recovery is less likely once the environment is altered more or less permanently by pollution, dredging, etc., Johannes (1975) provided evidence of partial recovery of a reef subjected to a nuclear blast. He described a brief survey made in 1971 of some shallow patch-reef communities at Enewetak Atoll which had been destroyed by a nuclear blast sometime in 1958. Dead standing colonies of tabular Acropora corymbosa dominated the shallow lagoon slopes. There was extensive regrowth of this species with some colonies measuring up to $3 \mathrm{~m}$ in diameter but compared with typical Acropora-dominated reefs elsewhere on Enewetak, coral diversity was low.

\section{RECOVERY OF CORAL COMMUNITIES DAMAGED BY Acanthaster planci}

I share the view of Endean and co-workers that coral damage on the Great Barrier Reef caused by Acanthaster infestations during the last 10 to $15 \mathrm{y}$ has been more extensive and dramatic than that caused by any other natural or man-made disturbance. Large aggregations of Acanthaster are capable of killing the bulk of corals on an average-size reef in just a few years (Chesher, 1969; Pearson and Endean, 1969; Endean, 1973). Damage is not confined to reef flats as in the case of exposure during extreme low tides or to reef slopes shallower than $20 \mathrm{~m}$ as in the case of severe storms. Instead, damage extends from the reef flat to the limit of coral growth which on the Great Barrier Reef usually exceeds $40 \mathrm{~m}$ (Pearson and Endean, 1969).

Recovery of coral communities following Acanthaster infestations has been investigated on the Great Barrier Reef and at Guam.

\section{Recovery at Guam}

In a series of papers Randall $(1973 a, b, c)$ presented data on a detailed investigation of Guam's reefs before 
Table 2. Comparison of coral communities at two sites on reefs at Guam before (1969) and after Acanthaster infestations (1970, 1971). Data from Randall (1973 a, b, c). Dashes: data not comparable as different methods were used

\begin{tabular}{lccccccccc}
\hline & & $\begin{array}{c}\text { Reef front } \\
(0-6 \mathrm{~m})\end{array}$ & & \multicolumn{3}{c}{$\begin{array}{c}\text { Submarine terrace } \\
(6-18 \mathrm{~m})\end{array}$} & \multicolumn{2}{c}{$\begin{array}{c}\text { Seaward slope } \\
(18-35 \mathrm{~m})\end{array}$} \\
& 1969 & 1970 & 1971 & 1969 & 1970 & 1971 & 1969 & 1970 & 1971 \\
\hline No. genera & 32 & 24 & 21 & 28 & 24 & 27 & 26 & 21 & 30 \\
No. species & 98 & 70 & 68 & 73 & 47 & 70 & 57 & 32 & 61 \\
\% cover & 49.1 & 20.9 & 21.9 & 59.1 & 0.9 & 4.0 & 50.1 & 0.5 & 2.1 \\
No. colonies & - & 632 & 789 & - & 320 & 632 & - & 161 & 521 \\
\hline
\end{tabular}

Table 3. Comparison of coral colony sizes and growth forms at two sites on reefs at Guam before (1969) and after Acanthaster infestations $(1970,1971)$. Data from Randall (1973 a, b, c). Branching growth forms included corymbose, caespitose and arborescent; 'other' growth forms included foliaceous, flabellate, phaceoloid, columnar and solitary

\begin{tabular}{|c|c|c|c|c|c|c|c|c|}
\hline & & \multicolumn{3}{|c|}{$\begin{array}{l}\text { Reef front } \\
(0-6 \mathrm{~m})\end{array}$} & \multicolumn{2}{|c|}{$\begin{array}{c}\text { Submarine } \\
\text { terrace } \\
(6-18 \mathrm{~m})\end{array}$} & \multicolumn{2}{|c|}{$\begin{array}{c}\text { Seaward slope } \\
\quad(18-35 \mathrm{~m})\end{array}$} \\
\hline & & 1969 & 1970 & 1971 & 1970 & 1971 & 1970 & 1971 \\
\hline \multirow{4}{*}{$\begin{array}{c}\text { Colony size } \mathrm{cm} \\
(\% \text { freq. })\end{array}$} & $0-5$ & 27.1 & 49.6 & 41.3 & 85.9 & 71.4 & 83.9 & 82.1 \\
\hline & $6-20$ & 43.0 & 43.8 & 53.8 & 14.0 & 28.2 & 16.1 & 17.7 \\
\hline & $21-40$ & 22.6 & 0.5 & 4.0 & 0 & 0.5 & 0 & 0.2 \\
\hline & $>41$ & 7.3 & 0.1 & 0.9 & 0 & 0 & 0 & 0 \\
\hline \multirow{4}{*}{$\begin{array}{c}\text { Growth form } \\
\text { (\% freq.) }\end{array}$} & massive & 25.4 & 20.3 & 15.5 & 12.8 & 7.0 & 8.7 & 10.7 \\
\hline & encrusting & 24.4 & 59.5 & 62.2 & 78.1 & 84.3 & 80.7 & 80.0 \\
\hline & branching & 43.6 & 18.6 & 21.4 & 7.8 & 5.2 & 5.0 & 4.6 \\
\hline & other & 6.6 & 1.6 & 0.9 & 1.3 & 3.5 & 5.6 & 4.7 \\
\hline
\end{tabular}

and after a major Acanthaster outbreak. Unfortunately, direct comparisons of the before and after situation at the two sites (Tumon Bay and Tanguisson Point) are not always possible using Randall's data, as different transect methods were used in the two areas. In addition, the Tumon Bay transects were not examined in detail below $6 \mathrm{~m}$ which was where the highest coral mortality was recorded at the Tanguisson Point site. Nevertheless, some comparisons are possible (Tables 2 and 3). In terms of generic and species diversity, recovery was almost complete by 1971 . According to Randall (1973b), 'the high number of genera surviving Acanthaster planci predation, even though at low density, may be essential in the recovery of devastated reefs if diversity of seed populations is an important prerequisite'. There was a dramatic decline in coral cover after the Acanthaster impact, but within another year the coral cover had increased fourfold. This was reflected in the number of colonies which almost doubled on the submarine terrace and more than tripled on the seaward slope. Most of these colonies were small $(<5 \mathrm{~cm})$ in both 1970 and 1971, although a slight increase in number of larger corals was evident in 1971 reflecting growth of the 1970 colonies (Table 3). When coral growth forms were compared (Table 3), encrusting colonies dominated the submarine terrace and seaward slope. This is not surprising, as recently established corals invariably adopt an encrusting growth form, occupy space quickly and establish a firm base for subsequent upward growth. Randall (1973c) estimated that it would take 20 y for recovery of the submarine terrace and $31 \mathrm{y}$ for the seaward slope. He warned that these estimates might be inaccurate and that it might take a much longer period, perhaps hundreds of years, for the reef to attain the massive framework development once found in the area. Resurveys of Randall's transects would now be most valuable.

\section{Recovery Elsewhere in the Indo-Pacific Ocean}

One interesting observation of apparent recovery concerns underwater observations made to depths of $75 \mathrm{~m}$ at Cocos Keeling Atoll in 1974 (Colin, 1977). Extensive areas of dead corals were noted on the reef slopes; the cause of death being attributed to Acanthaster, which was abundant ( 1 ind. $\left.200-400 \mathrm{~m}^{-2}\right)$ on the reef slopes. Colin observed that: 'Some signs of initial recovery by the populations of stony corals was evident. In some areas on the outer margin small colonies of Acropora were apparent. At present the stony coral populations at Cocos Keeling Atoll are low. Hopefully these reefs are now initiating natural recovery, but this will take a considerable period of time.' It is worth noting that Acanthaster may have been responsible for the extensive coral damage observed 
Table 4. Comparison of coral growths on undamaged reefs and on reefs damaged by Acanthaster. Data from a photographic survey by Endean and Stablum (1973b; their Table 2). The area of each print was approximately $1 \mathrm{~m}^{2}$

\begin{tabular}{|c|c|c|c|c|c|c|c|}
\hline & $\begin{array}{l}\text { No. } \\
\text { reefs }\end{array}$ & $\begin{array}{c}\text { No. } \\
\text { transects }\end{array}$ & $\begin{array}{c}\text { No. } \\
\text { quadrats }\end{array}$ & $\begin{array}{c}\text { Mean live } \\
\text { coral cover } \\
\text { print }^{-1}\end{array}$ & $\begin{array}{l}\text { Mean no. } \\
\text { recolonizers } \\
\text { print }^{-1}\end{array}$ & $\begin{array}{l}\text { Mean no. } \\
\text { surviving } \\
\text { colonies print }\end{array}$ & $\begin{array}{l}\text { Mean no. } \\
\text { all colonies } \\
\text { print }^{-1}\end{array}$ \\
\hline Undamaged & 2 & 2 & 24 & 51.2 & 0 & 6.8 & 6.8 \\
\hline Damaged & 9 & 17 & 167 & 7.1 & 1.6 & 1.0 & 2.6 \\
\hline
\end{tabular}

by Darwin (1860) in more than a mile square area of the lagoon at Cocos Keeling Atoll (Branham, 1973). In the same paper, Branham briefly reports on recolonization of a 'dead' reef in the lagoon of Arno Atoll, Marshall Islands: 'A dense aggregation of $A$. planci was seen there in July 1968, and most of the coral was dead the following summer. Considerable recolonization was noted in 1971. Small colonies, averaging about $10 \mathrm{~cm}$ in maximum dimensions, of 25 species of coral (in 16 genera) were found in densities of about 20 colonies per square metre over the reef surface. The observed species diversity was greater than would be expected on an established reef'.

Nishihira and Yamazato (1974) observed extensive damage to the reefs around Okinawa caused by Acanthaster infestations and human interference. Human interference included dredging and reclamation, construction, land development and erosion, release of red clay from a quarry, and oil and chemical pollution. In some areas they found evidence of hard-coral recolonization, in others alcyonarians dominated the reef, while at still other localities algae such as Turbinaria and Sargassum were dominant. Unfortunately, Nishihira and Yamazato did not distinguish clearly between recovery following Acanthaster depredations and recovery following human interference. Thus determination of the recovery process following Acanthaster depredations alone is not possible, especially when the authors state in their summary that The degree of human interference in any region is approximately proportional to the density of starfish.

\section{Recovery on the Great Barrier Reef}

In contrast to Randall's detailed transect studies, Endean and Stablum (1973a,b) conducted a much broader, less specific investigation of damage and recovery on reefs of the Great Barrier Reef They visually surveyed 55 sites on 21 reefs offshore between Cairns and Townsville, mostly between November 1970 and May 1971. An additional 16 sites on 8 reefs were inspected in August and October 1971 (Endean, 1974). Large aggregations of Acanthaster were active on some of these reefs in October 1966 (Pearson and Endean, 1969), on others Acanthaster was abundant in
1970 (Endean and Stablum, 1973a). However, as indicated by Endean and Stablum (1973b; their Table 1), accurate estimates are not available for the years when Acanthaster was active at most of the sites surveyed. This leads to a degree of imprecision as to how long recovery had been underway when the sites were surveyed. At most sites the authors observed only slight or negligible recolonization.

In support of these visual assessments of recovery Endean and Stablum obtained data on recovery from photographs taken of a total of 191 square-metre quadrats along 19 transects on 11 reefs. Images of live corals visible on the photographic prints were cut out and weighed. From this procedure, data on percentage coral cover and number of colonies $\mathrm{m}^{-2}$ were obtained. Details of the method are given in Endean and Stablum $(1973 a, b)$ and more fully in Laxton and Stablum (1974). Using this photographic method, Endean and Stablum (1973b) found that live coral cover on reefs considered to have been damaged by Acanthaster was low compared with that recorded at two undamaged sites, and there were few 'recolonizers' at the damaged sites (Table 4). Endean and Stablum $(1973 a, b)$ made a number of other observations and comments on damage and recovery which are discussed later (p. 118).

The accuracy of their method is open to question when used on recovering reef slopes where there are likely to be many small corals. In my experience even the best underwater photographs taken of reef substrata at distances of $1.5-2 \mathrm{~m}$, do not enable small colonies, especially those less than $5 \mathrm{~cm}$ diameter, to be detected. Thus estimates of the number of small corals (recolonizers) per square metre can be greatly underestimated on reefs in the early stages of recovery. Another criticism of the method is that its accuracy does not appear to have been tested by comparing it with direct measurements of corals within the quadrats. Laxton and Stablum (1974) at one point do refer to 'actual values' but these do not appear to have been obtained by direct measurement. They also claim to be able to identify from the photographs, 'many of the common reef corals, soft coral, hydroids and sponges to species level'. This would be especially difficult on a recovering reef where there may be many small young colonies

My studies of recovery on reefs of the Great Barrier 
Reef damaged by Acanthaster centre on three aspects. Firstly, a broad impression of recovery has been obtained from a series of quadrat samples made along transects on a number of reefs located off the north Queensland coast near Innisfail. Secondly, detailed information on recovery has been obtained from two small permanent study plots established in 1972 on the upper seaward slopes of Feather and Ellison Reefs located off Innisfail. Thirdly, detailed information has been obtained from several small permanent study plots established in 1974 at different depths on John Brewer Reef located off Townsville. Some initial results were presented in Pearson $(1974,1975 \mathrm{~b})$. Some recent results are presented here.

\section{Transect Surveys of Reefs off Innisfail}

Acanthaster infestations were first reported on reefs off Innisfail in October 1966; by 1969 starfish had disappeared from most of these reefs and extensive coral mortality was observed in most areas (Pearson and Endean, 1969). In 1971 R. N. Garrett and I made a number of transect surveys on the seaward slopes of some of these reefs; see Pearson (1974) for details. The transects ran perpendicular to the reef edge from the reef flat, down the reef slope to various depths (max. $27 \mathrm{~m}$ ), depending on several factors particularly the type of substratum. At intervals along each transect a metre quadrat was used to record the number of species $\mathrm{m}^{-2}$, the number of small colonies $\mathrm{m}^{-2}$ (colonies measuring less than $1 \%$ of the quadrat, i.e. $10 \times$ $10 \mathrm{~cm}$ ), and the number and percentage cover of large colonies (more than $1 \%$ of the quadrat). Most transects were resurveyed in 1977, again with the assistance of Garrett. On some transects, exactly the same metre quadrats were re-measured as stakes were used to mark the location of these quadrats (Transects 7, 9, 10 , 11, 12, 21, 22, in Fig. 1). In some other cases the transect was repeated within $10 \mathrm{~m}$ or so of the 1971 transect (Transects 1, 2, 3, 4, 6, 19). For the remaining transects it was impossible to relocate the original sites. In these cases the later transects may have been located up to $100 \mathrm{~m}$ from the earlier ones (Transects 14 , 18). Figure 1 illustrates in almost all cases substantial increases in the parameters measured, indicating recovery.

\section{Permanent Study Areas : (i) Ellison Reef}

A permanent study area, $10 \mathrm{~m} \times 1 \mathrm{~m}$, was established on the upper reef slope ( 2 to $3 \mathrm{~m}$ depth) at the northern end of Ellison Reef in April 1972. Censuses of all corals within the plot were made in April 1972,
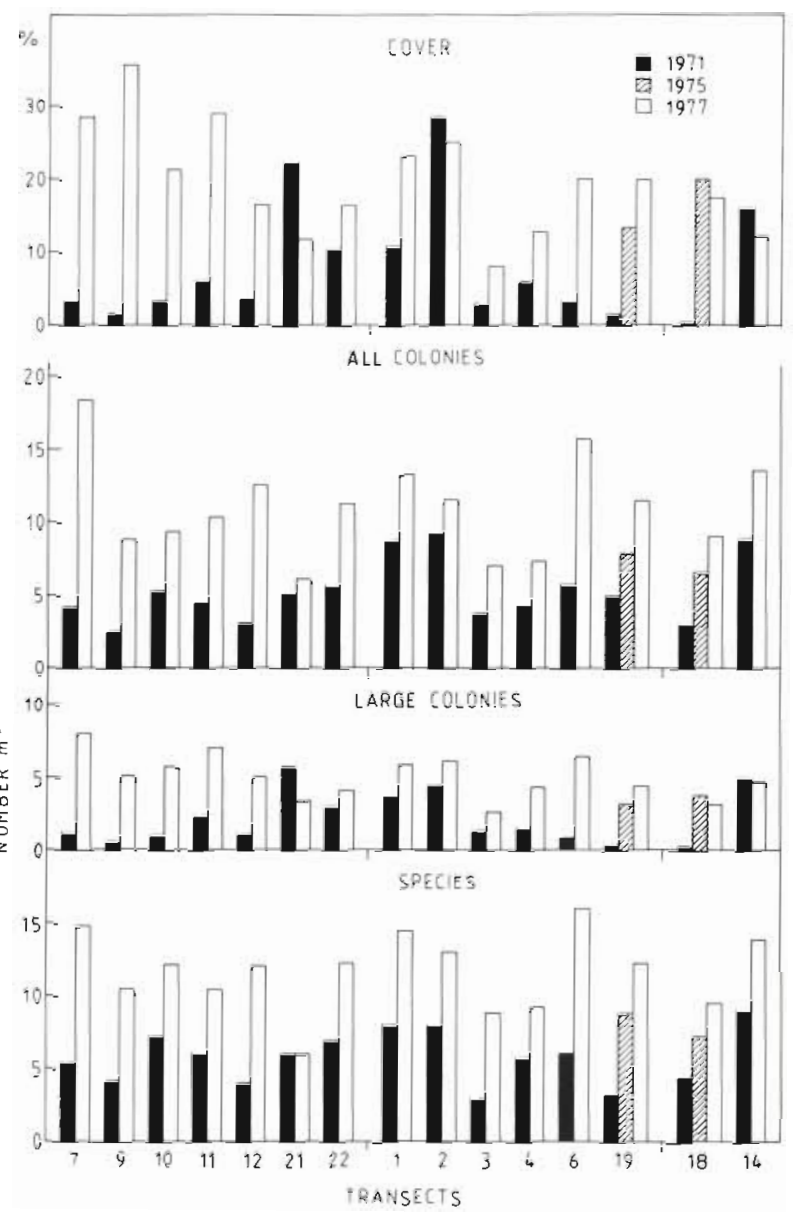

Fig. 1. Summary of data on hard coral growths obtained from metre quadrats along 15 transects on reefs off Innisfail, north Queensland, which were damaged by Acanthaster in the mid 1960 's. See text for details. Transect locations are given in Pearson (1974)

October 1972, October 1973, April 1974, April 1975, and December 1978. In addition, using a specially constructed tripod, a series of vertical underwater colour photographs were taken at each census to serve as a permanent record. These photographs proved to be of little use as a record of the changes which took place. Most small colonies and colonies overtopped by others, could not be detected. Only more obvious changes such as the growth, death, or dislodgement of large colonies - were noted in the photographs. A series of oblique photographs of the plot taken in April 1972, January 1975 and December 1977, are shown in Figures $2 \mathrm{a}, \mathrm{b}, \mathrm{c}$.

Recovery was not obvious from the surface when the study area was chosen. It was only after the study plot was established and a careful examination made of the substrate that many small colonies ( $>3 \mathrm{~mm}$ diameter) were detected. Initially there were 449 coral colonies within the $10 \mathrm{~m}^{2}$ plot, $72 \%$ of which measured less than $5 \mathrm{~cm}$ in diameter including 111 colonies $<2 \mathrm{~cm}$. 

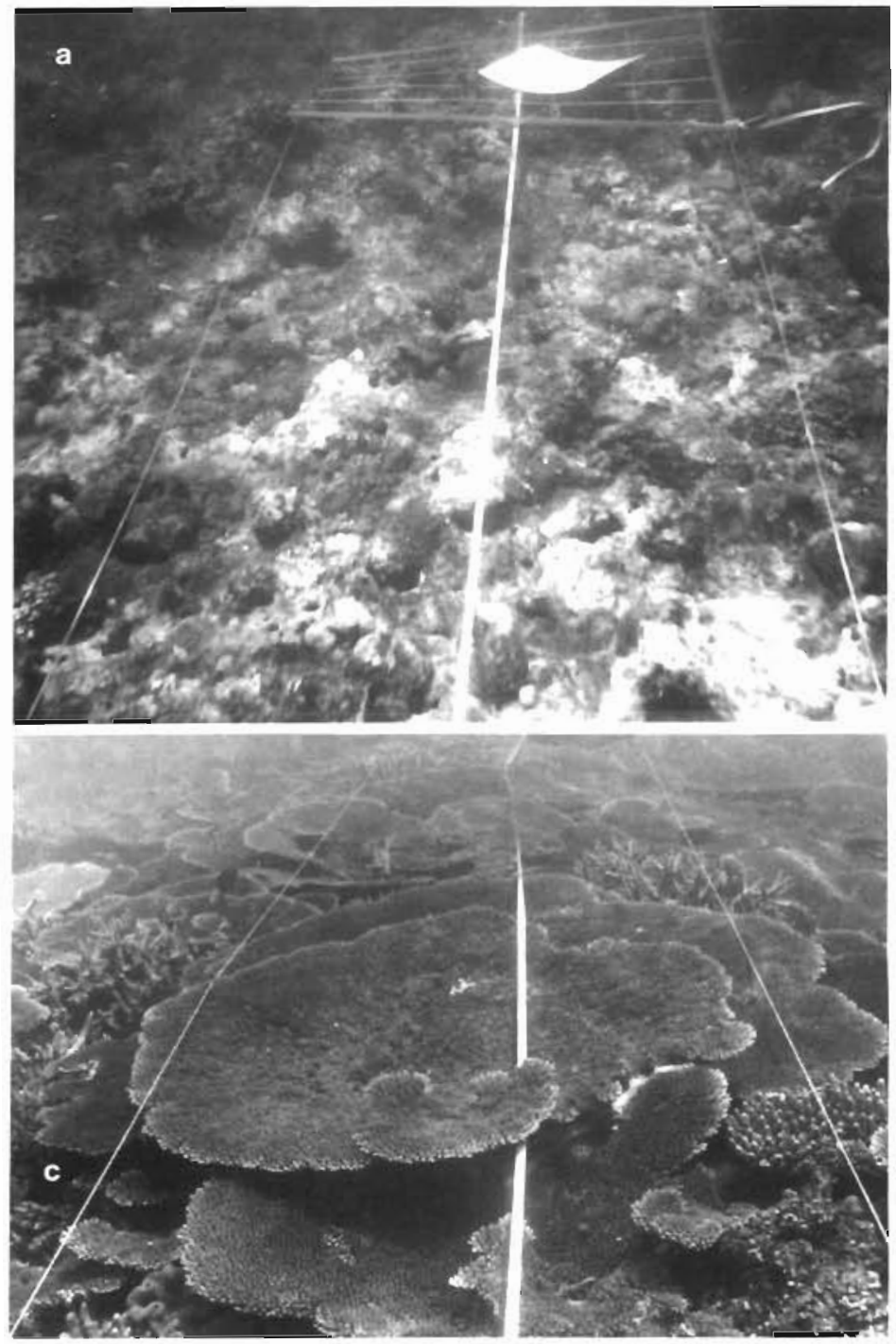

Fig. 2. Photographs of Ellison Reef permanent study plot (10 $\mathrm{m} \times 1 \mathrm{~m}$ ) showing growth of, and dominance by, colonies of tabular Acropora spp. (a) April 1972 (b) January 1975, (c) December 1977; (a) and (b) depict the same area, i.e. metre quadrats 5 (foreground) and 6 (centre); (c) depicts quadrat 4 (foreground) and 5 (centre)

There were also a few larger colonies (all $<30 \mathrm{~cm}$ ) which had survived the Acanthaster infestations of the mid 1960's. Coral cover was only $2.6 \%$ and average colony size $4.4 \mathrm{~cm}$. Because of the small size of most corals it was not possible to identify them to species or even to genus level in some cases. Acropora was the dominant genus comprising $59.0 \%$ of all colonies followed by Favia/Favites/Goniastrea (10.0\%) Porites $(9.3 \%)$ and Galaxea (3.4\%). None of the other 18 genera exceeded $3 \%$ of the total colonies. Surprisingly, the opportunistic genera Pocillopora, Stylophora and Seriatopora were represented by only 11 colonies $(2.4 \%)$. The proportion of unidentified corals was $4.1 \%$.

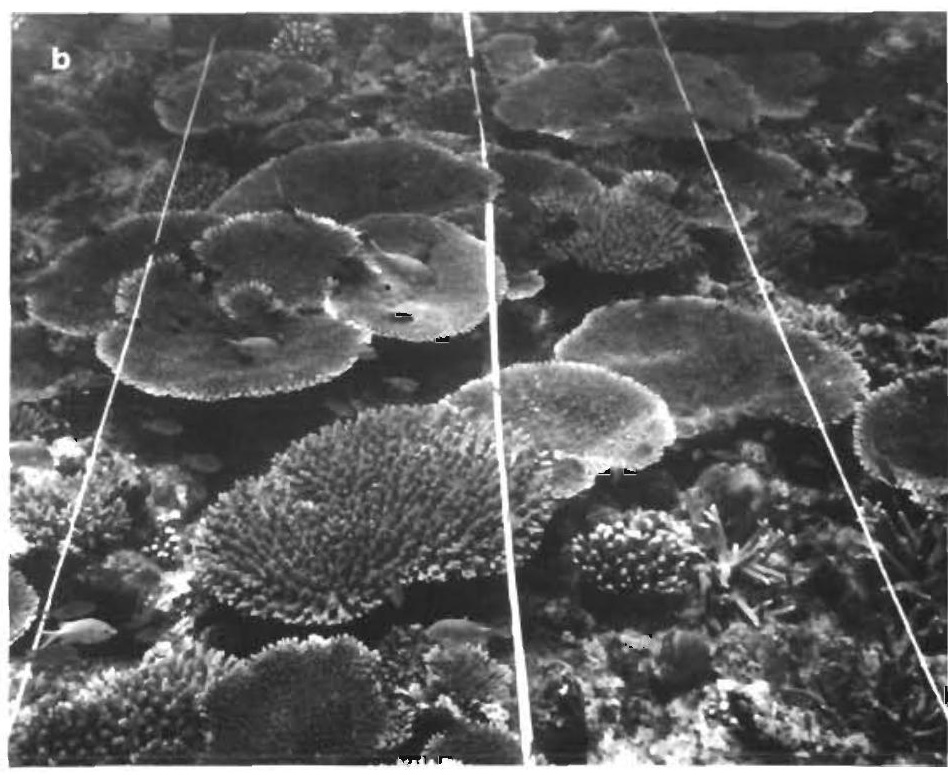

During the next 3 years to April 1975, the number of corals had increased to 528, coral cover had risen to $60.0 \%$ and average colony size was $11.6 \mathrm{~cm}$. The rapid growth of large numbers of tabular and plate-like forms of Acropora was largely responsible for the rapid increase in coral cover. By April 1975 these corals were beginning to compete for space with one another as well as overtopping smaller, slower growing species, and eventually causing their death.

Even more dramatic changes took place over the following $3.7 \mathrm{y}$. Coral cover rose to $80.6 \%$ and average colony size increased from 11.6 to $36.7 \mathrm{~cm}$. However, the total number of colonies dropped to 119. The loss of over 400 colonies can be attributed to overtopping by the increasingly dominant, fast-growing colonies of tabular, corymbose and staghorn Acropora, which now represented $71.2 \%$ of all colonies. The next more common genera were Seriatopora $(5.1 \%)$ and Porites $(5.1 \%)$. Over the entire $6.7 \mathrm{y}$, annual death rates calculated from the number of deaths recorded in each census interval $(0.5,1.0,0.5,1.0$ and 3.7 years $)$ barely changed from 11.2 deaths $\mathrm{m}^{-2} \mathrm{y}^{-1}$ in the first census interval to 11.7 deaths $\mathrm{m}^{-2} \mathrm{y}^{-1}$ in the last census interval. However, the recruitment rate did alter substantially. During the first $3 y$ the net rate of recruitment fluctuated between 12.8 and 18.6 recruits $\mathrm{m}^{-2}$ $\mathrm{y}^{-1}$. This dropped to 0.7 recruits $\mathrm{m}^{-2} \mathrm{y}^{-1}$ over the next 3.7 y. Only 27 new colonies were recorded between April 1975 and December 1978. One likely explanation for this failure of recruitment is that there was little space available for settlement of new colonies. The interesting exception to this was the first metre square of the plot where 22 of the 27 new colonies were located. In this square, coral cover was only $18.3 \%$ in December 1978 compared with the next lowest value 
of $64.8 \%$ for a single metre square. In April 1975 coral cover in the first square was $38.8 \%$, but it decreased as several large colonies were lost through dislodgement by heavy wave action. Repeated observations within and outside the plot revealed that this was not an uncommon occurrence especially in the case of large colonies of tabular Acropora. Although these corals grow rapidly, quickly occupying space and overtopping other corals, they are more susceptible to storm damage because of their narrow central stems and broad flat tops. In this regard the experimental studies of the breakage of colonies of the plate coral Acropora reticulata are of note. Vosburgh (1977) showed that this coral could not withstand normal wave action above $7.7 \mathrm{~m}$ depth on the windward reef terrace at Enewetak Atoll. In fact it only occurred below $8-10 \mathrm{~m}$, yet in the sheltered lagoon large colonies occurred in less than $2 \mathrm{~m}$. Vosburgh noted extensive damage to these shallow lagoon colonies following a storm in 1972. It would appear likely that if severe storms occur at regular intervals, other slower growing, more robust species would obtain a competitive advantage in shallow water.

\section{(ii) Feather Reef}

A permanent study plot $(10 \mathrm{~m} \times 1 \mathrm{~m})$ was established on the northern end of Feather Reef in February 1972 in a habitat similar to the one on Ellison Reef. Five coral censuses were made between February 1972 and October 1975. The area was revisited in December 1978 but no coral census was made. Instead, a series of standard vertical photographs were taken (as had been done on all previous censuses) to serve as a permanent record of the more obvious changes.

Results of the censuses were similar to those obtained for the Ellison Reef plot. Initially there were 394 colonies, of which $66 \%$ measured less than $5 \mathrm{~cm}$ in diameter, only 8 measured more than $20 \mathrm{~cm}$ in diameter and none exceeded $30 \mathrm{~cm}$. Coral cover was $12.3 \%$ and average colony size was $5.1 \mathrm{~cm}$. Acropora was again the most common genus $(39.6 \%$ of all colonies), followed by Porites (22.3\%) and Galaxea (10.9\%). None of the other 16 identified genera exceeded $10 \%$ of colonies, and $8.6 \%$ of all colonies could not be identified as to genus. Recovery was obviously well underway less than 6 y after Acanthaster infestations were reported from this part of the reef (Pearson and Endean, 1969). Yet as was the case at Ellison Reef, this recovery was not noticeable during surface swims over the area prior to the setting-up of the plot.

During the next $3.7 \mathrm{y}$, colony numbers rose to a maximum of 714 in November 1974 but then declined to 594 in October 1975. Coral cover also rose to a maximum of $63 \%$ in November 1974 but then declined to $60 \%$ in October 1975 . Net recruitment during the four census intervals $(0.7,1.3,0.8$, and $0.9 \mathrm{y})$ ranged from 14.6 to 46.4 recruits $\mathrm{m}^{-2} \mathrm{y}^{-1}$. There was no obvious explanation for the high recruitment recorded between February and November 1974, Mortality varied between 12.7 and 37.4 deaths $\mathrm{m}^{-2} \mathrm{y}^{-1}$. Of the corals present in October 1975, 43.7\% were Acropora, followed by Galaxea (7.2\%), Porites $(6.7 \%)$ and PocilIopora $(5.5 \%)$. There were 17 other genera, but $26 \%$ of all colonies could not be identified. This large proportion of unidentified corals was due to the large number (196) of small colonies $(<2 \mathrm{~cm}$ ). The presence of many small colonies affected average colony size, which was only $7.3 \mathrm{~cm}$ in October 1975, compared with $7.7 \mathrm{~cm}$ in February 1974. Colony growth was more marked for those pre-February 1972 colonies which survived to October 1975. For these corals average colony size increased from $5.1 \mathrm{~cm}$ to $18.1 \mathrm{~cm}$. There were only 5 colonies larger than $50 \mathrm{~cm}$ and none exceeded $80 \mathrm{~cm}$.

Photographs taken of the plot in December 1978 showed changes almost as dramatic as those documented for Ellison Reef. Colonies of tabular and staghorn Acropora dominated the plot although not to the same extent as at Ellison Reef.

(iii) John Brewer Reef

Studies of recovery were initiated on John Brewer Reef in July 1974. It was one of the most extensively damaged reefs which I had visited during surveys of several hundred reefs since 1966. Acanthaster infestations caused extensive damage during 1969 and 1970 (Endean and Stablum, 1973a,b). In addition Cyclone Althea, which struck the city of Townsville in December 1971, passed almost directly over John Brewer Reef. As a result the upper reef slopes and reef crest which had partially escaped Acanthaster predation were extensively damaged (Pearson, unpubl.). To obtain some data on the influence of depth on recovery, 2 permanent metre quadrats were established at depths of $6 \mathrm{~m}$ and $12 \mathrm{~m}$ at 2 sites on the seaward slope, and at 1 site at a depth of $3 \mathrm{~m}$ on the leeward slope. Four censuses were made; in July 1974, July 1975, November 1976 and December 1978. Data are presently available for only 5 of these quadrats, 1 at each site and depth. A permanent $10 \mathrm{~m}$ line transect marked at each end with steel stakes passed through the 2 quadrats at each depth (Fig. 3).

To compare the results at the 3 depths, data were pooled for quadrats at the same depth at each of the 2 sites on the seaward slope. A summary of the results shows that there have been increases in every parameter measured except soft coral cover (Table 5). Average net rates of recruitment for the 4.4 y study period at the 
3 depths were 23.7 recruits $\mathrm{m}^{-2} \mathrm{y}^{-1}(-3 \mathrm{~m}), 22.5$ $(-6 \mathrm{~m})$ and $12.4(-12 \mathrm{~m})$. Average mortality rates were 14.1 deaths $\mathrm{m}^{-2} \mathrm{y}^{-1}(-3 \mathrm{~m}), 14.4(-6 \mathrm{~m})$ and 10.8 $(-12 \mathrm{~m})$. While these rates are comparable to those recorded in the Feather and Ellison Reef study areas, they do indicate a reduced turnover of colonies in deeper water. Coupled with reduced colony growth (Table 5) it is apparent that recovery will take longer in deeper water.

With respect to diversity, colonies of Acropora were not nearly so dominant as they were on Feather and Ellison Reefs. On the leeward slope, Acropora constituted $30 \%$ of all colonies, followed by Favia/Favites/ Goniastrea (6.7\%) and Fungia (4.7\%); whereas on the seaward slope at $-6 \mathrm{~m}$. Acropora constituted $22.1 \%$ of all colonies, followed by Fungia $(16.8 \%)$ and Porites $(11.7 \%)$; and at $-12 \mathrm{~m}$, Acropora constituted only $11.5 \%$ of all colonies, followed by Porites (10.8\%) and Fungia $(10.8 \%)$.

\section{FACTORS INFLUENCING RECOVERY AND RECOLONIZATION}

In discussing factors influencing coral recovery and recolonization the following three points need to be considered. Firstly, most workers visualize coral communities as conforming to some successional sequence which in the absence of disturbance leads to the development of a climax coral assemblage. However, it is not clear what constitutes a climax community, how it might differ from one locality to another, or what time-scale is involved. Nor has there been any detailed explanation of the factors involved in the replacement of one coral assemblage by another in the successional sequence. Secondly, external disturbances of various forms modify the successional process to the extent that a periodic disturbance may maintain a coral community at a sub-climax stage. Thirdly, coral settlement is influenced by both the successional process and any disturbance. Furthermore, the factors influencing coral settlement and survival may themselves be modified by disturbances. Our understanding of the recovery process and our ability to predict the likely outcome of a particular disturbance will remain limited until basic knowledge in these three areas has accumulated.

For example, further studies of coral reproduction, larval dispersal and current patterns around and between reefs are urgently needed before reasonable predictions can be made of the relative contribution to the recolonization of denuded areas by larvae released from surviving corals on the same reef, or from corals on other undamaged reefs. There are indications that both might occur, although hard data are lacking. For example, Shinn (1972) suggested that damaged reefs in the Persian Gulf were recolonized by coral larvae originating from undamaged reefs located $60 \mathrm{~km}$ away. Loya (1976a) considered that damaged reef flats in the Red Sea were recolonized by larvae from corals on the undamaged reef slopes nearby. Endean and Stablum (1973b) observed that there appeared to be a relationship between the rate of recovery of an area of reef and the extent of coral destruction in the area caused by the starfish initially', implying that larvae from surviving corals had recolonized denuded areas nearby.

A crucial factor in these considerations is the length of time spent in the plankton by coral larvae. If it is a general rule that larvae spend only a short time in the plankton, and perhaps even settle near their parents, then recovery on extensively damaged reefs would be prolonged. There is field and laboratory evidence of this for only one species, Favia fragum (Lewis $1974 \mathrm{a}, \mathrm{b})$. There are only a handful of species from which planulae have been obtained and studied including, interestingly enough, the opportunistic species Pocillopora damicornis, Stylophora pistillata, and Seriatopora hystrix (Marshall and Stephenson, 1933; Abe, 1937; Atoda, 1947 a,b, 1951 a,b,c; Edmonson, 1946; Harrigan, 1972; Loya, 1976b,c). These studies have shown that most planulae settle within 1 or $2 \mathrm{~d}$. Stimson (1978) has suggested that for branching corals which apparently do not planulate, asexual reproduction by means of colony fragments may be the

Table 5. Influence of water depth on coral recovery in permanent metre quadrats on John Brewer Reef between July 1974 and December 1978. Data for \% cover of hard and soft corals obtained from permanent $10 \mathrm{~m}$ line transects

\begin{tabular}{|c|c|c|c|c|c|c|}
\hline & \multicolumn{2}{|c|}{$-3 m$} & \multicolumn{2}{|c|}{$-6 \mathrm{~m}$} & \multicolumn{2}{|c|}{$-12 m$} \\
\hline & 1974 & 1978 & 1974 & 1978 & 1974 & 1978 \\
\hline$\%$ cover hard corals & 6.0 & 45.2 & 7.3 & 41.1 & 4.8 & 19.7 \\
\hline$\%$ cover soft corals & 0.1 & 1.5 & 7.2 & 3.7 & 6.4 & 4.0 \\
\hline No. colonies $\mathrm{m}^{-2}$ & 53 & 86 & 49.5 & 88.5 & 26.0 & 42.5 \\
\hline Average colony size $(\mathrm{cm})$ & 3.6 & 6.9 & 4.3 & 7.1 & 4.5 & 6.2 \\
\hline $\begin{array}{l}\text { Average colony size }(\mathrm{cm}) \\
\text { (pre-July } 1974 \text { colonies only) }\end{array}$ & 3.6 & 13.9 & 4.3 & 15.1 & 4.5 & 10.1 \\
\hline No. colonies $>10 \mathrm{~cm}$ & 1 & 14 & 7 & 35 & 4 & 15 \\
\hline
\end{tabular}




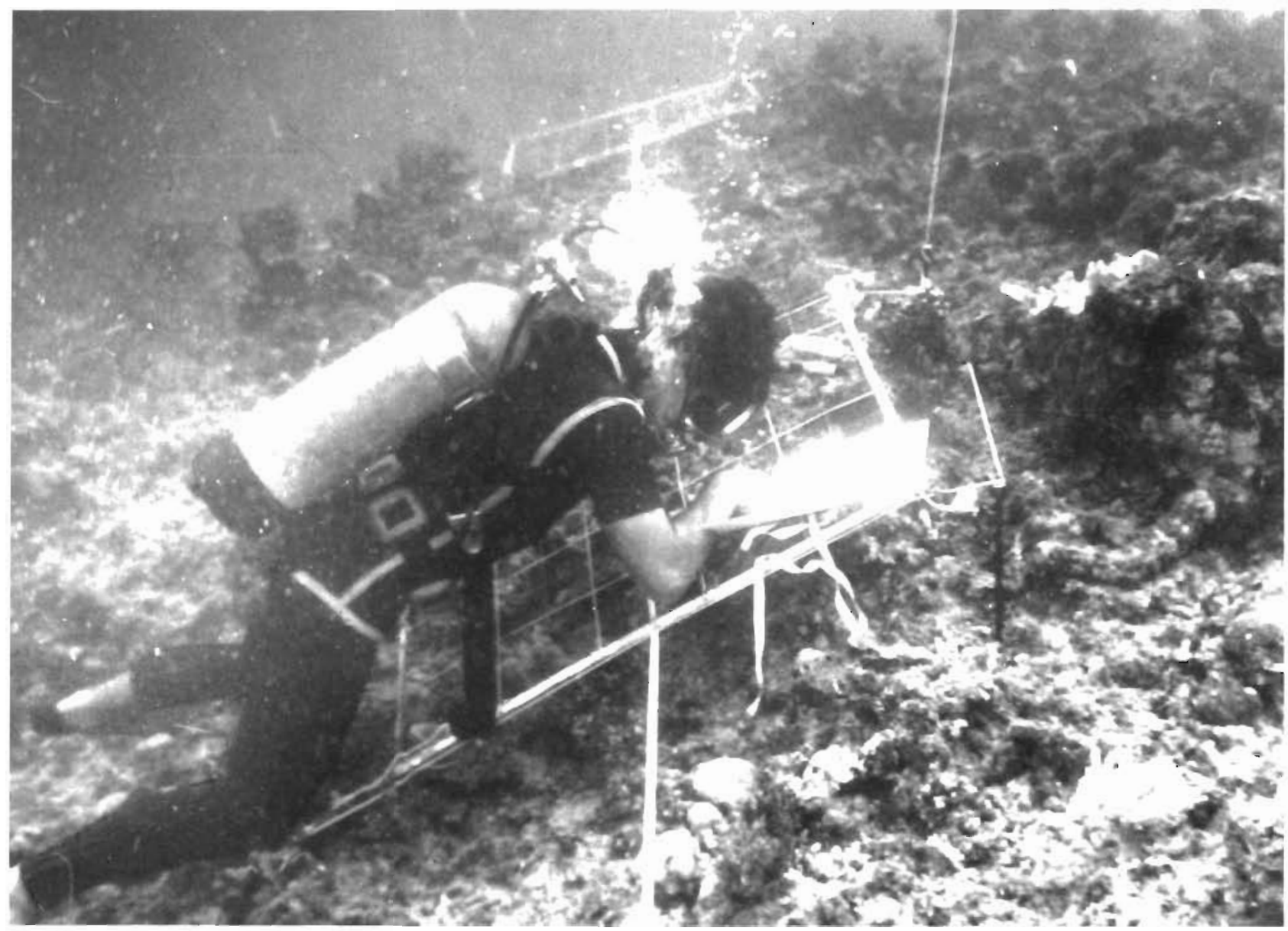

Fig. 3. Permanent study area located at $12 \mathrm{~m}$ depth on the seaward slope of John Brewer Reef showing arrangement of the two $1 \mathrm{~m}^{2}$ quadrats and the $10 \mathrm{~m}$ line transect

normal mode of reproduction. The proportion of coral species in which external fertilization occurs is unknown although Connell (1973) considered internal fertilization to be more common.

There are few field studies of larval settlement, substrate selection and survival of very young corals. Before corals are able to settle on new surfaces there appears to be a period of at least 1 y during which the substrate is 'conditioned'. Several workers have commented on this. For example Grigg and Maragos (1974) noted that Montipora verrucosa did not appear on larva flows younger than $10 y$, yet it was common on control reefs. Schuhmacher $(1974,1977)$ found that hard corals did not settle on granite boulders submerged for less than 1 y. Even on older boulders corals preferred to settle on limestone encrustations such as dead shells, calcareous algae and foraminifera. Loya (1976c) observed that many more colonies of Stylophora pistillata settled on PVC pipes during the second year of submergence than during the first. As all these substrata are not normally found on coral reefs it is difficult to relate their periods of 'conditioning' to those of natural reef substrates. For natural reef substrates any period of 'conditioning' is probably related to the time required for the establishment of those algal communities favourable as surfaces for larval settlement, survival and growth. Successional stages occur in the development of reef algal communities (Littler and Doty, 1975; Benayahu and Loya, 1977; Borowitzka et al., 1978). If unchecked by grazers, these lead to a climax community of fleshy frondose and filamentous algae on which corals are unlikely to settle and survive. However, under normal conditions of intense grazing, especially by fish and echinoids, the growth of these algae is inhibited as many workers have shown (e. g., Stephenson and Searles, 1960; Randall, 1961, 1974; Sammarco et al., 1974; Birkeland, 1977; Wanders, 1977). Under these conditions sub-climax communities of crustose coralline algae are maintained which would otherwise be smothered. Although experimental evidence is lacking (Bak, 1976, p. 325) these crustose corallines appear to offer a more suitable substratum for coral settlement. They provide a clean, firm surface unlike filamentous algal mats 
which are efficient sediment traps. Corals which settled on artificial substrata were usually found on vertical faces or undersurfaces where sedimentation was reduced (Schuhmacher, 1974, 1977). Loya (1976c) observed that grazing by sea urchins was restricted to the upper surfaces of artificial substrates presumably because of the greater algal cover. He suggested that coral settlement on the upper surfaces was prevented by the synergistic effect of intensive grazing and sedimentation. On the other hand, Birkeland (1977) observed that while corals grew faster on the upper surfaces of artificial substrates, sedimentation reduced their survival. Yet he found no instances of fish grazing on, or removing coral recruits. In fact Acanthurids and schools of Scarus croicensis avoided corals as small as $3 \mathrm{~mm}$. 'There were often small coral recruits with tooth marks all around them, but the corals were never touched by the tooth marks' (Birkeland, 1977). While some herbivorous fish evidently avoid grazing on recently settled corals, other species as well as echinoids may not. Both groups are capable of feeding on larger corals (Glynn, 1973; Randall, 1974; Bak and van Eys, 1975; Neudecker, 1977; Glynn et al., 1978; and others). Dart (1972), on the other hand, suggested that grazing on algal mats by echinoids may enhance coral recruitment by providing bare surfaces for settlement. Experimental studies are urgently needed to resolve these disparate views on the role of grazers in coral settlement and survival.

Recovery of coral communities is likely to be prolonged if the catastrophic event which destroyed the corals also reduced the number of grazers. Glynn (1968) reported on mass mortalities of sea urchins on reef flats. It is possible that severe storms may destroy grazers themselves and/or their refuges. Coral settlement in these situations could be inhibited as algal growths would flourish in the absence of grazers. One could predict that recovery would be faster after Acanthaster depredations as, all other factors being equal, grazers are not killed and dead coral skeletons may still provide them with adequate refuges from predation.

On reef slopes planed more or less smooth by severe storms, recovery is likely to be retarded if less surface area is available for settlement through a reduction in the diversity of surface orientations and configurations such as vertical faces, undersurfaces, crevices and ridges, all of which appear to be more important than horizontal surfaces in ensuring successful coral settlement (Lewis, 1974 a; Schuhmacher, 1974, 1977; Birkeland, 1977). In field experiments on factors influencing coral settlement which involve artificial substrata, more attention should be paid to (a) the total surface area provided for settlement, given that average recruitment rates are of the order of 1 to 50 colonies $\mathrm{m}^{-2} \mathrm{y}^{-1}$ (Connell, 1973; this paper); (b) the 'conditioning' period of the substratum; (c) the surface relief including provision of crevices and ridges; (d) substratum orientation.

In discussing factors affecting recovery following Acanthaster damage, Endean (1976) mentioned two which he considered likely to impede hard-coral recolonization. Firstly, in instances where corals settled on dead coral skeletons he suggested that many of these would ultimately be lost when the dead corals to which they were attached collapsed or crumbled. There appears to be little evidence to suggest that this phenomenon is widespread. Unless storms were to intervene one would expect more or less a balance between erosional forces at work on the dead skeletons and the binding and cementing actions of crustose coralline algae and other secondary frame builders (Bak, 1976). Even where dead corals do collapse there is a reasonable chance that live corals growing on them would continue to grow over and consolidate the dead fragments. Secondly, Endean (1976) observed that 'within a few months after a reef has been devastated by $A$. planci, an obvious increase in the alcyonarian cover particularly in lagoons and back reef areas occurred. Frequently, these soft corals grew over the skeletons of corals killed by Acanthaster. Several photographs of large soft-coral colonies were presented in support of these observations (Endean, 1973; his Fig. 7; Endean and Stablum 1973a; their Figs 14 and 15; 1973b, their Figs 15 and 16). Other workers have remarked on the apparent rapid growth of soft corals and their overgrowth of hard corals (Fishelson, 1970, 1973; Maragos, 1974; Nishihira and Yamazato, 1974; Schuhmacher, 1974). Benayahu and Loya (1977) erroneously stated that no quantitative data existed on the growth rates of soft corals. Available data show that soft corals occupy space at about the same rates as hard corals (Cary, 1931; Stephenson and Stephenson, 1933). Over a period of several months Mergener and Svoboda (1977) detected little growth of soft corals within a $25 \mathrm{~m}^{2}$ study area, although they recorded the disappearance of numbers of soft-coral colonies and the settiement of others. In a study of soft-corai growth rates and interactions with hard corals, Garrett (1975, unpubl.) found that recruitment and mortality of hard corals was not directly related to soft-coral cover and that soft-coral growth rates were comparable with those recorded by Cary (1931) and Stephenson and Stephenson (1933). Furthermore he found that the outcome of interactions between hard and soft corals was not only related to their competitive abilities but also to environmental conditions. These data do not support the view by Endean (1976) and others that soft corals rapidly cover hard corals killed by Acanthaster.

Apart from their frequency and intensity, the actual 
location of disturbances on reefs is likely to be another important factor governing the rate of recovery. The most rapid recovery is expected in those parts of the reef where conditions for coral settlement and growth appear most favourable, such as the upper seaward reef slope. Recovery after Acanthaster depredations appears to be slower in habitats less favourable for corals, such as reef flats, enclosed lagoons with little water circulation, and on deeper reef slopes (Endean, 1974; Pearson, 1974). On deeper reef slopes where Acanthaster predation is probably the most significant catastrophic event, several factors are likely to influence coral recovery. These include: lower light intensities which reduce coral growth rates (Bak, 1976); less water movement and hence greater build-up of sediment which might impede coral settlement; and reduced grazing pressure (Glynn, 1973; Bak, 1976; Van de Hoek et al., 1978) which enables fleshy algae to proliferate, thus further impeding coral settlement. Data obtained at different depths at John Brewer Reef suggest a slower rate of recovery in deeper water (12 m) (Table 5). In contrast, after Acanthaster damage at Guam there were only slight differences in recovery between coral communities in depths of $6-18 \mathrm{~m}$ and those at $18-35 \mathrm{~m}$ (Table 2).

Studies of disturbances of coral communities as well as their subsequent recovery can assist in the development of ideas and theories of diversity and patchiness in the community structure of coral reefs (e. g. Dayton, 1971; Goreau et al., 1972; Loya, 1972, 1976 a; Porter, 1972, 1974; Connell, 1973, 1975, 1976, 1978; Grassle. 1973; Grassle and Sanders, 1973; Levin and Paine, 1974; Maragos, 1974; Dana, 1976; Fishelson, 1977). Such studies can also provide inputs for models of coral communities, such as the one developed by Maguire and Porter (1977), and the succession model first suggested by Grigg and Maragos (1974). Ideas on the mechanisms of community succession have been reviewed by Connell and Slatyer (1977), but the actual mechanisms which enable some coral species to settle, survive and grow, so as to replace 'opportunistic' species, have yet to be elucidated. The role of chance in the re-establishment of coral communities has not been investigated.

\section{SUMMARY}

The evidence available indicates that several decades are required for recovery of most coral communities affected by major natural disturbances. There is less evidence available on recovery following manmade disturbances, but the indications are that full recovery may be prolonged or prevented altogether because of permanent change to the environment, or a continuation of chronic, low-level disturbances.
Deficiencies in almost all studies preclude a generalized account of recovery and recolonization. Most investigations have not been continued long enough, adequate baseline data are meagre or lacking altogether, usually the degree of damage has not been carefully documented, and few reef sites other than reef flats and upper reef slopes have been investigated. Furthermore there are many gaps in our knowledge of the life histories of even the most common hard corals.

Acknowledgements. I thank R. Garrett for assistance in the field and J. H. Choat, R. Hudson, N. Holmes and B. Goldman for their valuable comments on earlier drafts of this contribution.

\section{LITERATURE CITED}

Abe, N. (1937). Post-larval development of the coral Fungia actiniformis palawensis Döderlein. Palao trop. biol. Stn Stud. 1: $73-93$

Atoda, K. (1947a). The larva and postlarval development of some reef-building corals. I. Pocillopora damicornis (Dana). Sci. Rep. Tôhoku Univ. (4th Ser., Biol.) 18: $24-47$

Atoda, K. (1947 b). The larvae and postlarval development of some reef-building corals. II. Stylophora pistillata (Esper). Sci. Rep. Tôhoku Univ. (4th Ser., Biol.) 18: 48-64

Atoda, K. (1951 a). The larva and postlarval development of reef-building corals. III. Acropora bruggemanni. J. Morph. 89: $1-15$

Atoda, K. (1951 b). The larva and postlarval development of the reef-building corals. IV. Galaxea aspersa Quelch. J. Morph. 89: $17-35$

Atoda, K. (1951 c). The larva and postlarval development of some reef-building corals. V. Seriatopora hystrix Dana. Sci. Rep. Tôhoku Univ. (4th. Ser., Biol.) 19: $33-39$

Baines, G. B. K., Beveridge, P. J., Maragos, J. E. (1974). Storms and island building at Funafuti Atoll, Ellice Islands. In: Cameron, A. M. et al. (eds) Proceedings of the second international symposium on coral reefs. Great Barrier Reef Committee, Brisbane 2: $485-496$

Bak, R. P. M. (1976). The growth of coral colonies and the importance of crustose coralline algae and burrowing sponges in relation with carbonate accumulation. Neth. $J$. Sea Res. 10:285-337

Bak, R. P. M., van Eys, G. (1975). Predation of the sea urchin Diadema antillarum Philippi on living coral. Oecologia (Berl.) 20:111-115

Banner, A. H. (1974). Kanehoe Bay, Hawaii: Urban pollution and a coral reef ecosystem. In: Cameron, A. M. et al. (eds) Proceedings of the second international symposium on coral reefs. Great Barrier Reef Committee, Brisbane 2: $685-702$

Benayahu, Y., Loya, Y. (1977). Seasonal occurrence of benthic-algae communities and grazing regulation by sea urchins at the coral reefs of Eilat, Red Sea. In: Taylor, D. L. (ed.) Proceedings of the third international coral reef symposium. University of Miami, Miami 1: $383-389$

Birkeland, C. (1977). The importance of rate of biomass accumulation in early successional stages of benthic communities to the survival of coral recruits. In: Taylor, D. L. (ed.) Proceedings of the third international coral reef symposium. University of Miami, Miami 1: 15-21 
Borowitzka, M. A., Larkum, I W. D., Borowitzka, L J (1978). A preliminary study of algal turf communities of a shallow coral reef lagoon using an artificial substratum. Aquat Bot. 5: $365-381$

Branham, J. M. (1973). The crown of thorns on coral reefs. Bio Science 23: $219-226$

Cary, L. R. (1931). Studies on the coral reefs of Tutuila, American Samoa with special reference to the alcyonaria Pap. Dept. mar. Biol. Carnegie Inst., Washington 27: $53-98$

Chesher, R. H. (1969). Destruction of Pacific corals by the sea star Acanthaster planci. Science, N. Y 165: 280-283

Colin, P. L. (1977). The reefs of Cocos-Keeling Atoll, eastern Indian Ocean. In: Taylor, D. L. (ed.) Proceedings of the third international coral reef symposium. University of Miami, Miami 1:63-68

Connell, J. H. (1973). Population ecology of reef-building corals. In: Jones, O. A., Endean, R. (eds) Biology and geology of coral reefs, Vol 2. Academic Press, London, pp $205-245$

Connell, J. H. (1975). Some mechanisms producing structure in natural communities: a model and evidence from field experiments. In: Cody, M. L., Diamond, J. (eds) Ecology and evolution of communities, Belknap Press, Cambridge pp. $460-490$

Connell, J. H. (1976). Competitive interactions and the species diversity of corals. In: Mackie, G. O. (ed.) Coelenterate ecology and behavior Plenum, New York, pp. $51-58$

Connell, J. H. (1978). Diversity in tropical rain forests and coral reefs. Science, N. Y 199: 1302-1310

Connell, J. H., Slatyer, R. O. (1977). Mechanisms of succession in natural communities and their role in community stability and organization. Am. Nat. 111: 1119-1144

Crossland, C. (1928). Notes on the ecology of the reef-builders of Tahiti. Proc. zool. Soc. Lond. 1928: $717-735$

Crossland, C. (1939). Further notes on the Tahitian barrier reef and lagoons. J. Linn. Soc. 40:459-474

Dahl, A. L. (1973). Surface area in ecological analysis: quantification of benthic coral-reef algae. Mar Biol. 23: $239-249$

Dahl, A. L., Lamberts, A. E. (1977). Environmental impact on a Samoan coral reef: a resurvey of Mayor's 1917 transect. Pacif. Sci. 31: 309-319

Dana, T F. (1976). Reef-coral dispersion patterns and environmental variables on a Caribbean coral reef. Bull mar Sci. 26: $1-13$

Dart, J. A. G. (1972). Echinoids, algal lawn and coral. recolonization. Nature, Lond. 239: 50-51

Darwin, C. (1860). The voyage of the Beagle. Natural History Library Edition, 1962. The Natural History Library, Anchor Books, Doubleday \& Co., New York

Davies, P. S., Stoddart, D. R., Sigee, D. C. (1971). Reef forms of Addu Atoll, Maldive Islands. Symp. zool. Soc. Lond. 28: $217-259$

Dayton, P. K. (1971). Competition, disturbance, and community organization: The provision and subsequent utilization of space in a rocky intertidal community. Ecol. Monogr 41: $351-389$

Edmonson, C. H. (1946). Behavior of coral planulae under altered saline and thermal conditions. Occ. Pap. Bernice P. Bishop Mus. 18: 283-304

Endean, R. (1973). Population explosions of Acanthaster planci and associated destruction of hermatypic corals in the Indo-West Pacific region. In: Jones, O. A., Endean, R. (eds) Biology and geology of coral reefs, Vol. 2. Academic Press, London, pp. $389-438$
Endean, R. (1974). Acanthaster planci on the Great Barrier Reef. In: Cameron, A. M. et al (eds) Proceedings of the second international symposium on coral reefs. Great Barrier Reef Commuttee, Brisbane 1: 563-576

Endean, R. (1976). Destruction and recovery of coral reef communities. In: Jones, O. A., Endean, R. (eds) Biology and geology of coral reefs, Vol. 3. Academic Press, London, pp. 215-254

Endean, R. (1977). Acanthaster planci infestations of reefs of the Great Barrier Reef. In: Taylor, D. L. (ed.) Proceedings of the third international coral reef symposium. University of Miami, Miami 1: 186-191

Endean, R., Stablum, W. (1973a). A study of some aspects of the crown-of-thorns starfish (Acanthaster planci) infestations of Australia's Great Barrier Reef. Atoll Res. Bull. 167: $1-52$

Endean, R., Stablum W (1973b). The apparent extent of recovery of reefs of Australia's Great Barrier Reef devastated by the crown-of-thorns starfish (Acanthaster planci). Atoll Res. Bull. 168: 1-26

Fishelson, L. (1970). Littoral fauna of the Red Sea: the population of non-scleractinian anthozoans of shallow waters of the Red Sea (Eilat). Mar. Biol. 6: 106-116

Fishelson, L. (1973). Ecological and biological phenomena influencing coral species composition on the reef tables at Eilat (Gulf of Aqaba, Red Sea). Mar. Biol. 19: 183-196

Fishelson, L. (1977). Stability and instability of marine ecosystems, illustrated by examples from the Red Sea. Helgoländer wiss. Meeresunters. 30: 18-29

Frankel, E. (1977). Previous Acanthaster aggregations in the Great Barrier Reef. In: Taylor, D. L. (ed.) Proceedings of the third international coral reef symposium. University of Miami, Miami 1: 201-208

Garrett, R. N. (1975). A preliminary report of studies on Great Barrier Reef octocorallia. In: Crown-of-thorns starfish seminar proceedings, Australian Government Publishing Service, Canberra, pp. 135-147

Gilmore, M. D., Hall, B. R. (1976). Life history, growth habits, and constructional roles of Acropora cervicornis in the patch reef environment. J. Sed. Petrol. 46: 519-522

Glynn, P. W (1968). Mass mortalities of echinoids and other reef flat organisms coincident with midday, low water exposures in Puerto Rico. Mar. Biol. 1: 226-243

Glynn. P. W (1973). Aspects of the ecology of coral reefs in the Western Atlantic region. In: Jones, O. A., Endean, R. (eds) Biology and geology of coral reefs, Vol. 2. Academic Press, London pp. $271-324$

Glynn, P. W., Wellington, G. M., Birkeland, C. (1978) Coral reef growth in the Galápagos: Limitation by sea urchins. Science, N. Y 203: 47-49

Goreau, T F (1959). The ecology of Jamaican coral reefs. I. Species composition and zonation. Ecology 40.67-90

Goreau, T. F., Lang, J. C., Graham, E. A., Goreau, P. D. (1972) Structure and ecology of the Saipan reefs in relation to predation by Acanthaster planci (Linnaeus). Bull. mar. Sci. 22: $113-152$

Grassle, J. F. (1973). Variety in coral reef communities. In: Jones, O. A., Endean, R. (eds) Biology and geology of cora] reefs, Vol. 2. Academic Press, London, pp. 247-270

Grassle, J. F., Sanders, H. L. (1973). Life histories and the role of disturbance. Deep Sea Res. 20: 643-659

Grigg, R. W. Maragos, J. E. (1974). Recolonization of hermatypic corals on submerged larva flows in Hawaii. Ecology $55: 387-395$

Harrigan, J. (1972). The planula and larva of Pocillopora damicornis: lunar periodicity of swarming and substratum selection behaviour, Ph. D. thesis. University of Hawaii 
Hedgepeth, J. (1973). The impact of impact studies. Helgoländer wiss. Meeresunters. 24:436-445

Hedley, C. (1925). The natural destruction of a coral reef. Sci. Rep. Gt Barrier Reef Comm. 1: 35-40

Johannes, R. E. (1975). Pollution and degradation of coral reef communities. In: Ferguson-Wood, E. J., Johannes, R. E (eds) Tropical marine pollution. (Elsevier Oceanography Series No. 12), Elsevier Scientific Publ., New York, pp. $13-51$

Lang, J. C. (1970). Inter-specific aggression within the scleractinian reef corals. Ph. D. thesis, Yale University

Laxton, J. H., Stablum, W. J. (1974). Sample design for quantitative estimation of sedentary organisms of coral reefs. Biol. J. Linn. Soc. 6: $1-18$

Levin, S. A., Paine, R. T. (1974). Disturbance, patch formation, and community structure. Proc. Nat. Acad. Sci. USA 71 : $2744-2747$

Lewis, J. B. (1974 a). The settlement behavior of planula larva of the hermatypic coral Favia fragum (Esper). J. exp. mar. Biol. Ecol. 15: 165-172

Lewis, J. B. (1974 b). Settlement and growth factors influencing the contagious distribution of some Atlantic corals. In: Cameron, A. M. et al. (eds) Proceedings of the second international symposium on coral reefs. Great Barrier Reef Committee, Brisbane 2: 201-206

Littler, M. M., Doty, M. S. (1975). Ecological components structuring the seaward edges of tropical Pacific reefs: The distribution, communities and productivity - ecology of Porolithon. J. Ecol. 63: 117-129

Loya, Y. (1972). Community structure and species diversity of hermatypic corals at Eilat, Red Sea. Mar. Biol, 13: $100-123$

Loya, Y (1976a). Recolonization of Red Sea corals affected by natural catastrophes and man-made perturbations. Ecology $57: 278-289$

Loya, Y (1976b). The Red Sea coral Stylophora pistillata is an r-strategist. Nature, Lond. 259: 478-480

Loya, Y $(1976 \mathrm{c})$. Settlement, mortality and recruitment of a Red Sea scleractinian coral population. In: Mackie, G. O. (ed.) Coelenterate ecology and behavior, Plenum, New York, pp. $89-100$

Maguire, L. A., Porter, J. W. (1977). A spatial model of growth and competition strategies in coral communities. Ecol. Modelling 3: 249-271

Maragos, J. E. (1974). Coral communities on a seaward reef slope, Fanning Island. Pacif. Sci. 28: 257-278

Marshall, S. M., Stephenson, T A. (1933). The breeding of reef anımals. Pt. 1. The corals. Scient. Rep. Gt Barrier Reef Exped. 3: 219-245

Mayor, A. G. (1924). Structure and ecology of Samoan reefs. Pap. Dept. mar. Biol. Carnegie Inst., Washington 19: 1-25

Mergener, H., Svoboda, A. (1977). Productivity and seasonal changes in selected reef areas in the Gulf of Aqaba (Red Sea). Helgoländer wiss. Meeresunters. 30: $383-399$

Neudecker, S. (1977). Transplant experiments to test the effect of fish grazing on coral distribution. In: Taylor, D. L. (ed.) Proceedings of the third international coral reef symposium. University of Miami, Miami 1:317-323

Nishihira, M., Yamazato, K. (1974). Human interference with the coral community and Acanthaster infestation of Okinawa. In: Cameron, A. M. et al. (eds) Proceedings of the second international symposium on coral reefs. Great Barrier Reef Committee, Brisbane 1: $577-590$

Ogg, J. G., Koslow, J. A. (1978). The impact of Typhoon Pamela (1976) on Guam's coral reefs and beaches. Pacif. Sci. 32: 105-118

Pearson, R. G. (1974). Recolonization by hermatypic corals of reefs damaged by Acanthaster. In: Cameron, A. M. et al. (eds) Proceedings of the second international symposium on coral reefs. Great Barrier Reef Committee, Brisbane 2: $207-215$

Pearson, R. G. (1975a). Coral reefs, unpredictable climatic factors and Acanthaster. In: Crown-of-thorns starfish seminar proceedings, Australian Government Publishing Service, Canberra, pp. 131-134

Pearson, R. G. (1975b). Further studies on recolonization by hermatypic corals of reefs damaged by Acanthaster. In: Crown-of-thorns starfish seminar proceedings, Australian Government Publishing Service, Canberra, pp. 127-129

Pearson, R. G., Endean, R. (1969). A preliminary study of the coral predator Acanthaster planci (L.) (Asteroidea) on the Great Barrier Reef. Fisheries Notes, Queensland Dept. Harbours and Marine 3: 27-55

Pichon, M. (1977). Recent studies on the reef corals of the Philippine Islands and their zoogeography. In: Taylor, D. L. (ed.) Proceedings of the third international coral reef symposium, University of Miami, Miami 1: 149-154

Pichon, M. (1978). Problems of measuring and mapping coral reef colonies. In: Stoddart, D. R., Johannes, R. E. (eds) Coral reefs: research methods, UNESCO, Paris, pp. $219-230$

Porter, J. W. (1972). Predation by Acanthaster and its effect on coral species diversity. Am. Nat. 106: 487-492

Porter, J. W. (1974). Community structure of coral reefs on opposite sides of the Isthmus of Panama. Science, N. Y 186: $543-545$

Rainford, E. H. (1925). Destruction of the Whitsunday Group fringing reefs. Aust. Mus. Mag. 2: 175-177

Randall, J. E. (1961). A contribution to the biology of the convict surgeonfish of the Hawaiian Islands, Acanthurus triostegus sandvicensis. Pacif. Sci. 15: 215-272

Randall, J. E. (1974). The effect of fishes on coral reefs. In: Cameron, A. M. et al (eds) Proceedings of the second international symposium on coral reefs. Great Barrier Reef Committee, Brisbane 1: 159-166

Randall, R. H. (1973a). Reef physiography and distribution of corals at Tumon Bay, Guam, before crown-of-thorns starfish Acanthaster planci (L.) predation. Micronesica 9: $119-158$

Randall, R. H. (1973b). Distribution of corals after Acanthaster planci (L.) infestation at Tanguisson Point, Guam. Micronesica 9: 213-222

Randall, R. H. (1973c). Coral reef recovery following extensive damage by the 'crown-of-thorns' starfish Acanthaster planci (L.). Publ. Seto mar biol. Lab. 20: 469-489

Randall, R. H., Eldredge, L. G. (1977). Effects of typhoon Pamela on the coral reefs of Guam. In: Taylor, D. L. (ed.) Proceedings of the third international coral reef symposium. University of Miami, Miami 2: 525-531

Rinkevich, B., Loya, Y. (1977). Harmful effects of chronic oil pollution on a Red Sea scleractinian coral population. In: Taylor, D. L. (ed.) Proceedings of the third international coral reef symposium. University of Miami, Miami 2: $585-591$

Sammarco, P. W., Levinton, J. S., Ogden, J. C. (1974). Grazing and control of coral reef community structure by Diadema antillarum Philippi (Echinodermata: Echinoidea): a preliminary study. J. mar. Res. 32: 47-53

Sanders, H. L. (1968). Marine benthic diversity: a comparative study, Am. Nat. 102: 243-282

Schubmacher, H. (1974). On the conditions accompanying the first settlement of corals on artificial reefs with special reference to the influence of grazing sea urchins (Eilat, Red Sea). In: Cameron, A.M. et al, (eds) Proceedings of the 
second international symposium on coral reefs. Great Barrier Reef Committee, Brisbane 1: 257-267

Schuhmacher, H. (1977). Initial phases in reef development, studied at artificial reef types off Eilat (Red Sea). Helgoländer wiss. Meeresunters. 30: 400-411

Shinn, E. A. (1963). Spur and groove formation on the Florida reef tract. J. Sed. Petrol. 33: 291-303

Shinn, E. A. (1972). Coral reef recovery in Florida and in the Persian Gulf. Environmental Conservation Department, Shell Oil Co., Houston, Texas

Sluiter, C. Ph. (1889). Einiges über die Entstehung der Korallenriffen in der Javasee und Brantweinsbai und über neue Korallenbildung bei Krakatau. Natuurk. Tijdschr. Nederl. Indië 49: $360-380$

Smith G. B. (1975). The 1971 red tide and its impact on certain reef communities in the mid-eastern Gulf of Mexico. Environ. Letters 9: 141-152

Stephenson, T. A., Stephenson, A. (1933). Growth and asexual reproduction in corals. Scient. Rep. Gt Barrier Reef Exped. 3: $167-217$

Stephenson, W., Searles, R. B. (1960). Experimental studies on the ecology of intertidal environments at Heron Island. I. Exclusion of fish from beach rock. Aust. J. mar. freshw. Res. 11: 241-267

Stephenson, W., Endean, R., Bennett, I. (1958). An ecological survey of the marine fauna of Low Isles, Queensland. Aust. J. mar. freshw. Res. 9: $261-318$

Stimson, J. S. (1978). Mode and timing of reproduction in some common hermatypic corals of Hawaii and Enewetak. Mar. Biol, 48: 173-184

Stoddart, D. R. (1963). Effects of Hurricane Hattie on the British Honduras reefs and cays, October 30-31, 1961 Atoll Res. Bull. 95: 1-142

Stoddart, D. R. (1969). Post-hurricane changes on the British
Honduras reefs and cays: re-survey of 1965. Atoll Res Bull. 131: 1-25

Stoddart, D. R. (1972). Catastrophic damage to coral reef communities by earthquake. Nature, Lond. 239: 51-52

Stoddart, D. R. (1974). Post-hurricane changes on the British Honduras Reefs: Re-survey of 1972. In: Cameron, A. M. et al. (eds) Proceedings of the second international symposium on coral reefs. Great Barrier Reef Committee, Brisbane 2: 473-483

Umbgrove, J. H. F. (1930). The end of Sluiter's coral reef at Krakatoa. Leidsche Geol. Meded. 3: 261-264

Van den Hoek, C., Breeman, A. M., Bak, R. P. M., van Buurt, G. (1978). The distribution of algae, corals and gorgonians in relation to depth, light attenuation, water movement and grazing pressure in the fringing coral reef of Curaçao, Netherlands Antilles. Aquat. Bot. 5: $1-46$

Vosburg, F. (1977). The response to drag of the reef coral Acropora reticulata. In: Taylor, D. L. (ed.) Proceedings of the third international coral reef symposium. University of Miami, Miami, 1: $477-482$

Wallace, C. C. (1978). The coral genus Acropora (Scleractinia: Astrocoeniina: Acroporidae) in the central and southern Great Barrier Reef Province. Mem. Qd Mus. 18: 273-319

Walsh, R. J., Harris, C. L., Harvey, J. M., Maxwell, W. G. H. Thomson, J. M., Tranter, D. J. (1971). Report of the committee on the problem of the crown-of-thorns starfish, C.S.I.R.O., Melbourne

Wanders, J. B. W. (1977). The role of benthic algae in the shallow reef of Curaçao (Netherlands Antilles). III: The significance of grazing. Aquat. Bot. 3: 357-390

Wood-Jones, F. (1907). On the growth-forms and supposed species in corals. Proc. zool. Soc. Lond. 2: $518-556$

Yamaguchi, M. (1975). Sea level fluctuations and mass mortalities of reef animals in Guam, Mariana Islands. Micronesica 11: $227-243$

Topic and author of this review were suggested by Dr. Y. Loya; the review was accepted for printing on November 5, 1980 